IRA-International Journal of Applied Sciences

ISSN 2455-4499; Vol.04, Issue 03 (2016)

Institute of Research Advances

Pg. no. 460-470

http://research-advances.org/index.php/IRAJAS

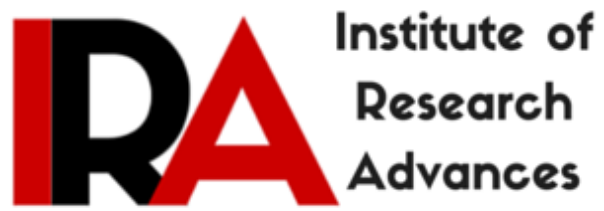

\title{
Monitoring of adult aquatic insect activities and ecological role in the riparian zone of streams in the Western Ghats, India
}

\author{
T. Kubendran ${ }^{1}$ and M.Ramesh ${ }^{1}$, \\ ${ }^{\mathbf{1}}$ Department of Zoology, Bharathiar University, Coimbarore-641046, \\ Tamil Nadu, India.
}

Type of Review: Peer Reviewed.

DOI: http://dx.doi.org/10.21013/jas.v4.n3.p10

\section{How to cite this paper:}

Kubendran, T., \& Ramesh, M. (2016). Monitoring of adult aquatic insect activities and ecological role in the riparian zone of streams in the Western Ghats, India. IRA-

International Journal of Applied Sciences (ISSN 2455-4499), 4(3), 460-470.

doi:http://dx.doi.org/10.21013/jas.v4.n3.p10

(C) Institute of Research Advances

(c) EY-NO

This work is licensed under a Creative Commons Attribution-Non Commercial 4.0 International License subject to proper citation to the publication source of the work.

Disclaimer: The scholarly papers as reviewed and published by the Institute of Research Advances (IRA) are the views and opinions of their respective authors and are not the views or opinions of the IRA. The IRA disclaims of any harm or loss caused due to the published content to any party. 


ABSTRACT
The Western Ghats, running parallel to the west coast of India between $8^{\circ} N$ and $21^{\circ} N$ is a prominent
feature of the peninsular India. In freshwater biodiversity hotspots like the Western Ghats, no
information is available on activates and ecological role of adult aquatic insect in the riparian zone
of streams. Most adult aquatic insects that emerge from streams live briefly in the nearby riparian
zone. Adult activities, such as mating dispersal and feeding influence their distribution in the
terrestrial habitat. An observation at Kurangani streams, Western Ghats, India has shown that both
numbers and biomass of adult aquatic insects are greatest in the near stream vegetation; however,
adult insects can be relatively common 1 to 10 feet from the stream. Why because, adult aquatic
insects are abundant and they are primary food resource for many riparian insectivores. The role of
adult aquatic insects in the riparian zone must be better understood for riparian and aquatic food
chain to be complete.

Keywords: aquatic insects, Western Ghats, riparian vegetation, insect activity

\section{Introduction}

The adult stages of most aquatic insects found in riparian zone (Anderson and Wallace, 1984; Erman, 1984). Although adult insects are generally short life span starts from one day to a week, they frequently exhibit morphological characteristics and life history traits that facilitate their survival in the terrestrial ecosystem and their reproductive success (Bulter 1984; Jackson 1988). Such adaptations suggest that the brief interaction between stream adult insects and the riparian habitat has been, and presumably continues to be, important to their survival. At the same time, stream insects can influence the distribution and abundance of riparian insectivores because the adult of aquatic insects represent an important primary food sources (Jackson and Fisher 1986; Jackson and Resh, 1989). The use of benthic macroinvertebrates is widespread and constitutes the basis for most aquatic biomonitoring programs currently in use (Metcalfe 1989; Rosenberg \& Resh 1993). The present study is to explain some ecological activities and roles of adult stream insects in riparian zones in Kurangani streams of Western Ghats, India.

\section{Description of study area}

The Western Ghats, running parallel to the west coast of India between $8^{\circ} \mathrm{N}$ and $21^{\circ} \mathrm{N}$ is a prominent feature of the peninsular India. In freshwater biodiversity hotspots like the Western Ghats, no information is available on activates and ecological role of adult aquatic insect in the riparian zone of streams. Such information is very important to understand the impact of ongoing degradation of the biodiversity of streams in general and insect communities in particular. This information will also aid in developing conservation strategies for the riverine ecosystems of tropical biodiversity hotspots such as the Western Ghats (Sivaramakrishnan et al., 1990). There is a high probability that anthropogenic activity will also result in a change in the composition of the benthic community (Plate 1).

\section{Riparian vegetation}

Along the banks of the stream are thick stands of trees, shrubs, whose leaves are the stream's principal source of organic detritus. Among the taller plants Bischofia javanica, Pongamia pinnata, Clerodendrum arboreum, Terminalia arjuna, Bombax sp, Mangifera indica and Lantana camera dominate the stream banks. Because of the leaf canopy cover, the stream formed by branched and leaning trees, there is a feeble exposure to direct sunlight even in midday. Most of the tree species lose leaves throughout the year, with increase in leaf litter fall in spring resulting from nutrient translocation of the vegetation (Rathinakumar et al., 2013). 


\section{Materials and Methods}

\section{Collection and field survey of adult emergence by visual observation and light trapping}

The aquatic insect samples were preserved in $80 \%$ Ethyl alcohol and stored in labelled vials. Collected samples were brought to laboratory and identified under steriobinocular microscope using standard taxonomic literature. Samples were assigned to family and genus using keys for that particular group. Following keys were used for identification; Ephemeroptera (Dudgeon, 1999 Sivaramakrishnan, 1990; Selvakumar et al., 2013; Kubendran et al 2014; 2015); Trichoptera (Wiggins, 1975).

Sampling method suggested by Sivaramakrishnan (1990) and Jackson et al., (1988) was followed for adult survey. The time of emergence, flying direction and flying height were determined before light trapping. The emergency light was placed near stream banks from 19.00 to 20.00 hours. The emerged insects from the stream were attracted towards light and collected by using fine forceps and brushes without morphological damage (Plate 1).

\section{Results and Discussion}

\section{Physico-chemical characteristics}

The variation in physico-chemical parameters were analyzed from Kurangani stream, Western Ghats during May 2012 to April 2013 (Table 1 and Table 2). The third order Kurangani stream is clear and odourless. The sampling site had substrate index 7.00 which consists of $20 \%$ bed rocky, $25 \%$ boulders, $25 \%$ cobbles, $15 \%$ gravels, $10 \%$ sand integrated with 5\% silts. Rathinakumar et al (2013) observed the average substrate index was 6.15 in Kurangani stream of Western Ghats, India. The stream averaged $5.5 \mathrm{~m}$ wide. Maximum depth was $25 \mathrm{~cm}$. The average water temperature was $20.5^{\circ} \mathrm{C}$ and Air temperature goes upto $27^{\circ} \mathrm{C}$. The lowest water temperature $19^{\circ} \mathrm{C}$ observed during the study period. Air temperature and Water temperature showed large fluctuation because of different seasons in Kurangani stream of Cardamom hills (Balasubramanian et al., 1992). The average $\mathrm{pH}$ was 7.04. The dissolved oxygen of Kurangani stream ranged 9.3 to 9.8. Sivaramakrishnan et al., (1995) reported While studying in tributaries of Kaveri river in Karnataka with different stream orders by have dissolved oxygen level between 4-8 mg/L. Rathinakumar et al., (2013) recorded range of dissolved oxygen 7.1 to $8.3 \mathrm{mg} / \mathrm{L}$ was recorded by from streams of southern Western Ghats.

\section{Adult aquatic insects taxa analysis}

A total of 15 genera, 10 families and 3 orders of adult aquatic insects were collected during investigational period. At the order level, (EPT) Ephemeroptera (Mayflies), Plecoptera (Stoneflies), and Trichoptera (Caddisflies) were predominant. Caddisflies found in more numbers followed by Mayflies and Stoneflies. At family level, Hydropsychidae, Baetidae, had contributed significantly to total abundance during light trapping. Perlidae also contributes maximum number of individuals followed by Leptophlebiidae and Caenidae. Genus Neoperla biseriata, Notophlebia jobi, and Caenis $s p$. were found to be high density followed by Baetis $s p$ and Hydropsyche sp. The taxa Neoperla biseriata and Caenis sp. were collected throughout the experimental period.

\section{Adult aquatic insect activities in streams}

The adult aquatic insects are involved in several activities, the most common of which are reproduction, dispersal and feeding. Adult insects must select mate location followed by oviposition in the stream or overhanging vegetation by females for reproduction. It is also essential for the initiation of the next generation in the aquatic environment. The reproductive activities are often well defined with respect to time of the day and location in the riparian zone. Some species form mating swarms like mayflies (Ephemeroptera), caddisflies (Tricoptera) and stoneflies (Plecoptera) at specific 
times of the day, distances from the stream and heights above the ground (Edmunds et al 1976; Lesage and Harrison 1980).

The previous studies in the northern California demonstrated that cadisflies of some male species locate conspecific females by following sex pheromones like chemicals that mediate reproductive activities between males and females are released by females (Wood and Resh 1984; Resh and Wood 1985). The similar to swarming, pheromone induced mating occurs at a specific time of the day. Jackson and Resh observed pheromone induce mating period for Gumaga nigricula (Trichoptera: Sercostomatidae) is in the early morning and lasts only 3-6 hours.

Dispersal is also a key activity for most adult aquatic insects. The short lived adult stage in many species like mayflies, stoneflies and caddisflies would appear to limit the distance that they can potentially disperse, either passively or actively. However, long distance i.e. greater than 8-10 feet movements both within stream corridors (Coutant 1982) and across land (Sevensson 1974; Edmunds et al 1976). Jahnson (1969) recorded for some species in these groups not surprising, long distance movements have been commonly observed in species that have relatively long-lived adults like blackflies, mosquitoes and dragonflies (Johnson 1969).

Predators like Long lived adults often feed blood meal for egg development and prey or host availability may contribute to the distance travelled. The effect that limited feeding activities like stoneflies feeding on young leaves and buds or on algae on tree trunks (Harper and Stewart 1984), caddisflies feeding on nectar or honeydew (Burtt et al 1986) and some aquatic insects dispersal distance has not been examined (Jackson and Resh 1988). The above activates contribute to the distribution and abundance of adults in the riparian zone. In a recent study of the distribution of adult aquatic insects in the evergreen forest of Kurangani stream (Western Ghats, TN, India), authors found that the abundance of adult aquatic insects was greatest near the stream and decreased as distance from the stream increased by using XY Plot graph analysis for single light trap (Fig. 1). The rate of decrease in abundance varied among species. Caddisflies, Hydropsyche sp. Potamiya sp. Macronema sp. Leptonema sp. Stenopsyche sp. (Trichoptera: Hydropsychidae, Stenopsychidae) were very abundant in the trees next to the stream. However, Macronema sp. was almost absent 10 feet from the stream whereas Hydropsyche sp. was still common 3-4 feet form the stream. Mayfly and stonefly Baetis sp, Caenis sp, Choroterpes sp, Notophlebia sp, Epeorus sp, Tricorythodes sp, Ephemera sp and Neoperla sp (Ephemeroptera and Plecoptera) were very abundant in the same area. By flying more than 4 feet form the stream, adult aquatic insects would be outside of most riparian zones that are recommended to protect water quality and aquatic life in streams (Brinson et al 1981).

Within the forest, most of the species observed in the Kurangani stream study exhibited one of two distribution patterns: adults were either equally abundant at all heights observed like 2,3,4,5,6,7 \&8 feet above the ground level or they were more abundant near the tree tops (above 6 feet) than at the tree bases ( 1 to 2 feet). Some of the undescribed species of the mayfly and caddisfly abundant near the tree bases than the tree tops.

\section{Ecological role of adult aquatic insects}

Larvae of aquatic insects are the secondary production of aquatic insectivores were reported in various studies have shown that between 5 percent and 60 percent of the biomass. The emerges from the aquatic system in the form of adult insects. Because many of these adults die in the riparian zone, much of this biomass does not return to the aquatic habitat. This export of biomass reduces the organic matter and nutrients that are available to aquatic insectivores like fishes, amphibians and other macroinvertebrates and increases organic matter and nutrients that are available to riparian insectivores like birds and bats. For riparian insectivores, the importance of this export of aquatic biomass depends on the abundance of adult aquatic insects as prey relative to the abundance of terrestrial insects as prey (Jackson and Fisher 1986). 
Adult aquatic insects represented 75 percent of total arthropod numbers and 50 percent of total arthropod biomass captured by emergency light traps placed in stream rock bed in trees 4 meter from stream. Adult aquatic insects are often major components in the diets of riparian birds (Clark 1984) and bats (Herd and Fenton 1983; Swift et al 1985), which suggests that this aquatic-terrestrial interaction may have contributed to the abundant insectivore faunas that characterize riparian systems. The potential importance of adult aquatic insects to riparian insectivores is greatest in arid region such as Kurangani because terrestrial insects may be less abundant in upland areas (Rathinakumar et al 2013).

\section{Implications for Management of Riparian Zones}

The consequence of the interaction between adult aquatic insects and the riparian zone are more important. However, adults have not been considered in the management of riparian systems. The anthropogenic activities on riparian zone can directly affect adult aquatic insects by interfering with the reproductive activities of adults. Some times abiotic changes like atmospheric temperature, wind velocity also affect the reproductive activities. In some times the biotic factors like insectivore density also affect the same. These conditions are exposed to in the riparian zone in the stream ecosystem. Indirect effects can include changes in the survival and growth of the immature stages of aquatic insects (i.e. larvae found in the stream) which in turn affects the abundance of adult aquatic insects in the riparian zone (Subramanian et al 2005).

The direct and indirect effect increases the complexity of management decisions. The availability of opening of stream canopy can increase the production of the immature stages of aquatic insects in the stream. As a result, larvae of aquatic insects would be more available as prey for stream insectivores, such as trout and adults would be more available as prey for riparian insectivores such as birds and bats. However, such type of alterations of the riparian zone may actually have a negative effect on stream biota because other essential stream parameters like water temperature, salinity, fee carbon dioxide, dissolved oxygen total solid suspended particles, stream width and breath, water velocity, substrate and index would also change (Hawkins et al, 1983). Birds and bats may be adversely affected as well if the survival and reproductive success of adult aquatic insects decrease because of alteration of the riparian zone due to anthropogenic activities (subsequently numbers in subsequent generations decrease (Jackson and Fisher 1986).

The factors that affect the distribution, abundance and function of the aquatic insects larvae in aquatic ecosystems have been examined extensively (Resh and Rosenberg 1984). In this context, very limited information only available for the adult stages of aquatic insects. If management plans for riparian zones are to be complete, further studies that implement the role of adult aquatic insects in riparian systems are needed in Western Ghats, south India.

\section{Acknowledgements}

We thank Prof. Dr. K. G. Sivaramakrishnan for constant support and encouragement for constructive criticism in preparation of this manuscript. The authors gratefully acknowledge DST-Science

Engineering Research Board (SERB), Government of India, New Delhi, for the award of National Post Doctoral Fellowship (F. No.PDF/2015/000945).

\section{References}

Anderson, N. H. Wallace, J. Bruce. (1984). Habitat, life history, and behavioural adaptations of aquatic insects. In: Merritt, Richard W.; Cummins, Kenneth W., Eds. An introduction to the aquatic insects of North America. $2^{\text {nd }}$ Ed. Dubuque, IA: Kendall/Hunt Publ. Co. 38-58. 
Brinson, M.M. Swift, B.L., Plantico, R. C. and Barclay J. S. (1981). Riparian ecosystems: their ecology and status. Kearneysville, WV: U.S. Fish and Wildlife Service; 154 p. Available from NTIS, Springfield, VA; PB 82-140369.

Burtt, E. T. Perry, R. J. O. and McLachlan, A. J. (1986). Feeding and sexual dimorphism in adult midges (Diptera: Chironomidae). Holarctic Ecology, 9(1):27-32.

Butler, M. G. (1984). Life histories of aquatic insects. In: Resh, Vincent H.; Rosenberg, David M., eds. The ecology of aquatic insects. New York: Praeger Publishers, 24-55.

Clark, T. O. (1984). Avifaunal studies in the Gila River Complex, eastern Arizona. Tempe: Arizona State University; 133 p. Thesis.

Coutant, C. C. (1982). Evidence for upstream dispersion of adult caddisflies (Trichoptera: Hydropsychidae) in the Columbia River. Aquatic Insects, 4(2):61-66.

Dudgeon D. (1999). Tropical Asian Streams: Zoobenthos, Ecology and Conservation, Hong Kong University Press.

Edmunds, G.F.J. Jensen, S L. and Berner, L. (1976). The mayflies of North and Central America. Minneapolis, MN: University of Minnesota Press; 330 p.

Erman, N. A. (1984). The use of riparian systems by aquatic insects. In: Warner, Richard E.; Hendrix, Kathleen M., eds. California Riparian Systems. Berkeley, CA: University of California Press; $177-182$.

Harper, P.P. and Stewart, K.W. (1984). Plecoptera. In: Merritt, Richard W.; Cummins, Kenneth W., eds. An introduction to the aquatic insects of North America. 2d ed. Dubuque, IA: Kendall/Hunt Publ. Co.; 182-230.

Hawkins, C. P., Murphy, M. L., Anderson, N. H. and Wilzbach, M. A. (1983). Density of fish and sala-manders in relation to riparian canopy and physical habi-tat in streams of the northwestern United States. Canadian Journal of Fisheries and Aquatic Sciences. 40(8):1173- 1185.

Herd, R. M. and Fenton, M.B. (1983). An electrophoretic, morphological, and ecological investigation of a putative hybrid zone between Myotis lucifugus and Myotis yumanensis (Chiroptera: Vespertilionidae). Canadian Journal of Zoology, 61(9):2029-2050.

Jackson, J., Resh, K and Vincent, H (1989). Distribution and Abundance of Adult Aquatic Insects in the Forest Adjacent to a Northern California Stream, 18, 2: 278-283.

Jackson, J.K and Resh, V.H (1989). Activities and ecological role of adult aquatic insects in the riparian zone of streams. USDA Forest Service Gen. Tech. Rep. PSW-110.

Jackson, J.K. (1988). Diel emergence, swarming and longevity of selected adult aquatic insects from a Sonoran Desert stream. American Midland Naturalist. 119(2):344- 352.

Jackson, J. K. and Fisher, S. G. (1986). Secondary production, emergence, and export of aquatic insects of a Sonoran Desert stream. Ecology 67(3):629-638.

Kubendran, T., Balasubramanian, C., Selvakumar, C. Gattolliat, J-L. and Sivaramakrishnan, K. G. (2015). Contribution to the knowledge of Tenuibaetis Kang \& Yang 1994, Nigrobaetis 
Novikova \& Kluge 1987 and Labiobaetis Novikova \& Kluge 1987 (Ephemeroptera: Baetidae) from the Western Ghats (India). Zootaxa. 3957 (2): 188-200.

Kubendran, T., Rathinakumar, T., Balasubramanian, C., Selvakumar, C and Sivaramakrishnan, K. G. (2014). A new species of Labiobaetis Novikova \& Kluge, 1987 (Ephemeroptera: Baetidae) from the southern Western Ghats in India, with comments on the taxonomic status of Labiobaetis. Journal of Insect Science. 14 (86) 1-10.

Metcalfe J.L. (1989). Biological water quality assessment of running waters based on macroinvertebrate communities: history and present status in Europe. Environment and Pollution. 60: 101-139.

Rathinakumar, T., Balasubramanian, C. and Kubendran, T. (2013) Decomposition of three leaf litter species and associated aquatic insects in Kurangani stream of Western Ghats, South India, International Journal of Environmental Biology, 4(2): 100-106.

Resh, V.H. and Wood,J.R (1985). Site of sex pheromone production in three species of Trichoptera. Aquatic insects. 7: 65-71.

Rosenberg, D. M. and Resh, V. H. (1993). Freshwater Monitoring and Benthic Macroinvertebrates. Chapman and Hall Publishers, New York.

Rosenberg, D.M and Resh, V.H (1993). Introduction to Freshwater Biomonitoring and Benthic Macroinvertebrates. Chapman and Hall, New York,1-194.

Selvakumar, C., Sundar, S and Sivaramakrishnan, K. G. (2012). Two new mayfly species (Baetidae) from India. Orienal Insects. 46(2): 116-129.

Sivaramakrishnan, K.G., S.Sridhar and K.Venkataraman (1990). Habitats, microdistribution, life cycle patterns and trophic relationships of mayflies of Cardamom hills of Western Ghats. Hexapoda (Insecta India) 2: 9-16.

Subramanian, K. A. and Sivaramakrishnan, K. G. and Gadgil. M, (2005). Impact of riparian landuse on stream insects of Khudremukh National Park, Karnataka state. India. Journal of Insect Science. 5: 49.

Svenssson, B.W. (1972). Flight periods, ovarian maturation and mating in Trichoptera at a south Swedish stream. Oikos. 12: 115-118.

Swift, M.C. and Forward, R.B. (1980). Photoresponsesof Chaoborus larvae. Journal of Insect Physiology. 26: 365-371.

Wiggins, B. (1975). Larvae of the North American Caddisfly Genera (Trichoptera). University of Toronto Press, Tronto. Pp.401.

Wood,J.R and Resh, V.H. (1984). Demonstration of sex pheromones in dacddisflies (Trichoptera). Journal of chemical Ecology. 10: 171-175. 
Table1. Physical characteristics of evergreen forest Kurangani stream of Western Ghats during experimental study May 2012 to April 2013

\begin{tabular}{|c|c|c|}
\hline S.No & Physical characteristics & Kurangani stream \\
\hline 1 & Latitude $(\mathrm{N})$ & $11^{\circ} .00^{\prime} \mathrm{N}$ \\
\hline 2 & Longitude (E) & $77^{\circ} .50^{\prime \prime} \mathrm{E}$ \\
\hline 3 & Altitude (m.a.s.l) & 650 \\
\hline 4 & Stream order & III \\
\hline 5 & Appearance & clear \\
\hline 6 & Colour & colourless \\
\hline 7 & Odour & odourless \\
\hline 8 & Canopy cover & Partially canopy cover \\
\hline \multirow{7}{*}{9} & \multicolumn{2}{|c|}{ Substrate composition Percentage (\%) } \\
\hline & a. Bed rock & 20 \\
\hline & b. Boulders & 25 \\
\hline & c. Cobbles & 25 \\
\hline & d. Gravels & 15 \\
\hline & e. Sandy & 10 \\
\hline & f. Silt & 5 \\
\hline 10 & Substrate Index & 7.0 \\
\hline
\end{tabular}




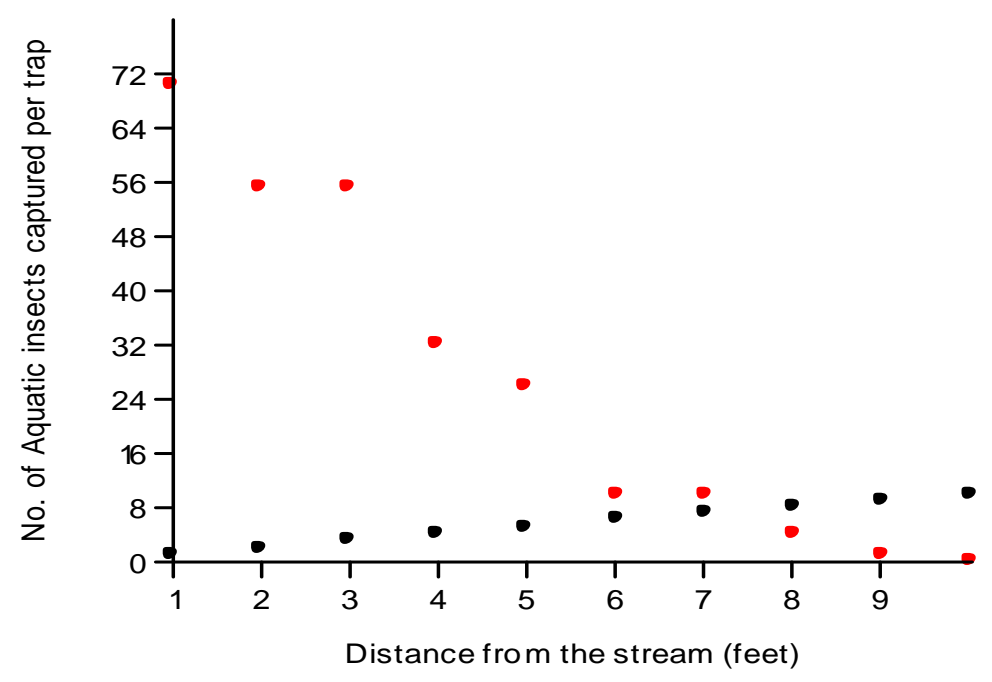

Fig1. XY Plot graph between distance from the stream and total number of adult aquatic insects captured per light trap set in the evergreen forest of Kurangani stream, Western Ghats, India. 
Table 2. Showing Physico-chemical parameters of Kurangani stream of Western Ghats during experimental study May 2012 to April 2013

\begin{tabular}{|c|c|c|c|c|c|c|c|c|c|c|c|c|}
\hline Parameters & May & June & July & Aug & Sep & Oct & Nov & Dec & Jun & Feb & Mar & April \\
\hline Water Temperature $\left({ }^{0} \mathrm{C}\right)$ & $21 \pm 0.47$ & $23 \pm 0.47$ & $23 \pm 0.47$ & $22 \pm 0.94$ & $21 \pm 0.47$ & $22 \pm 0.47$ & $22 \pm 0.94$ & $21 \pm 0.47$ & $21 \pm 0.47$ & $21 \pm 0.47$ & $23 \pm 0.47$ & $22 \pm 0.47$ \\
\hline Air Temperature $\left({ }^{0} \mathrm{C}\right)$ & $26 \pm 0.94$ & $26 \pm 0.47$ & $27 \pm 0.47$ & $25 \pm 0.94$ & $24 \pm 0.47$ & $24 \pm 0.47$ & $24 \pm 0.47$ & $25 \pm 0.47$ & $25 \pm 0.94$ & $25 \pm 0.94$ & $25 \pm 0.94$ & $26 \pm 0.94$ \\
\hline Water velocity (M/Sec) & $7.0 \pm 0.47$ & $7.4 \pm 0.12$ & $7.85 \pm 0.47$ & $8.0 \pm 0.47$ & $7.65 \pm 0.47$ & $8.2 \pm 0.47$ & $6.83 \pm 0.94$ & $7.2 \pm 0.47$ & $6.8 \pm 0.47$ & $7.9 \pm 0.47$ & $9.0 \pm 0.47$ & $6.5 \pm 0.21$ \\
\hline Width (M) & $8.7 \pm 0.12$ & $7.4 \pm 0.12$ & $6.9 \pm 0.47$ & $7.5 \pm 0.47$ & $7.8 \pm 0.47$ & $7.5 \pm 0.12$ & $7.9 \pm 0.94$ & $8.0 \pm 0.47$ & $8.2 \pm 0.21$ & $8.0 \pm 0.47$ & $7.5 \pm 0.47$ & $7.5 \pm 0.21$ \\
\hline Depth (M) & $0.3 \pm 0.12$ & $0.5 \pm 0.08$ & $0.6 \pm 0.12$ & $0.8 \pm 0.47$ & $0.8 \pm 0.47$ & $0.8 \pm 0.47$ & $0.6 \pm 0.12$ & $0.8 \pm 0.47$ & $0.8 \pm 0.21$ & $0.9 \pm 0.21$ & $1.0 \pm 0.07$ & $0.5 \pm 0.21$ \\
\hline Dissolved oxygen (mg/L) & $7.64 \pm 0.27$ & $9.07 \pm 0.03$ & $7.79 \pm 0.12$ & $7.28 \pm 0.12$ & $8.5 \pm 0.47$ & $7.9 \pm 0.12$ & $8.2 \pm 0.12$ & $8.0 \pm 0.47$ & $9.0 \pm 0.47$ & $9.1 \pm 0.47$ & $8.9 \pm 0.47$ & $8.2 \pm 0.47$ \\
\hline Free $\mathrm{CO}_{2}$ & $1.1 \pm 0.21$ & $1 \pm 0.04$ & $1 \pm 0.47$ & $1 \pm 0.47$ & $1 \pm 0.47$ & $1 \pm 0.21$ & $1 \pm 0.21$ & $1 \pm 0.21$ & $1 \pm 0.21$ & $1 \pm 0.21$ & $1 \pm 0.07$ & $1 \pm 0.07$ \\
\hline pH & $7.63 \pm 0.27$ & $7.93 \pm 0.06$ & $7.8 \pm 0.12$ & $7.85 \pm 0.12$ & $7.8 \pm 0.470 .12$ & $7.5 \pm 0.12$ & $7.8 \pm 0.47$ & $7.2 \pm 0.21$ & $7.7 \pm 0.47$ & $7.5 \pm 0.21$ & $7.5 \pm 0.47$ & $7.4 \pm 0.47$ \\
\hline Total Solids & $0.4 \pm 0.21$ & $0.56 \pm 0.06$ & $0.55 \pm 0.21$ & $0.75 \pm 0.21$ & $0.6 \pm 0.21$ & $0.02 \pm 0.21$ & $0.5 \pm 0.21$ & $0.09 \pm 0.21$ & $0.03 \pm 0.02$ & $0.41 \pm 0.21$ & $0.01 \pm$ & $0.56 \pm 0.21$ \\
\hline Dissolved Solids & $0.04 \pm 0.07$ & $0.1 \pm 0.04$ & $0.05 \pm 0.07$ & $0.09 \pm 0.07$ & $0.04 \pm 0.07$ & $0.02 \pm 0.07$ & $0.02 \pm 0.07$ & $0.01 \pm 0.07$ & $0.04 \pm 0.07$ & $0.06 \pm 0.07$ & $0.02 \pm 0.07$ & $0.02 \pm 0.07$ \\
\hline Suspended Solids & $0.36 \pm 0.07$ & $0.46 \pm 0.04$ & $0.45 \pm 0.21$ & $0.06 \pm 0.07$ & $0.56 \pm 0.07$ & $0.18 \pm 0.07$ & $0.06 \pm 0.07$ & $0.08 \pm 0.07$ & $0.05 \pm 0.04$ & $0.07 \pm 0.07$ & $0.06 \pm 0.07$ & $0.06 \pm 0.07$ \\
\hline
\end{tabular}


Table 3. Order, Family and Genera of the adult aquatic insects (EPT) collected from Kurangani stream of Western Ghats during experimental study May 2012 to April 2013

\begin{tabular}{|c|c|c|c|c|c|c|c|c|}
\hline Order & Family & Genera & May & June & July & Aug & Sep & Oct \\
\hline \multirow{7}{*}{ Ephemeroptera } & Beatidae & Beatis sp & $13 \pm 0.81$ & $16 \pm 0.81$ & $18 \pm 0.5$ & $13 \pm 0.81$ & $18 \pm 0.81$ & $10 \pm 0.81$ \\
\hline & \multirow{2}{*}{ Leptophlebiidae } & Choroterpes $s p$ & $24 \pm 0.47$ & $23 \pm 0.47$ & $12 \pm 0.47$ & $16 \pm 0.47$ & $18 \pm 0.47$ & $12 \pm 0.47$ \\
\hline & & Notophlebia $s p$ & $1 \pm 0.47$ & $6 \pm 0.81$ & $6 \pm 0.47$ & $3 \pm 0.47$ & $4 \pm 0.94$ & $4 \pm 0.47$ \\
\hline & Caenidae & Caenis $s p$ & $7 \pm 0.47$ & $9 \pm 0.47$ & $5 \pm 0.47$ & $6 \pm 0.47$ & $10 \pm 0.47$ & $8 \pm 0.81$ \\
\hline & Heptageniidae & Epeorus $s p$ & $10 \pm 0.81$ & $5 \pm 0.47$ & $9 \pm 0.47$ & $5 \pm 0.47$ & $11 \pm 0.47$ & $2 \pm 0.47$ \\
\hline & Tricorythidae & Tricorythodes $s p$ & $8 \pm 0.47$ & $14 \pm 0.99$ & $11 \pm 0.47$ & $10 \pm 0.47$ & $7 \pm 0.47$ & $15 \pm 0.99$ \\
\hline & Ephemeridae & Ephemera $s p$ & $8 \pm 0.47$ & $10 \pm 0.47$ & $10 \pm 0.47$ & $9 \pm 0.47$ & $4 \pm 0.47$ & $4 \pm 0.47$ \\
\hline Plecoptera & Perlidae & Neoperla $s p$ & $8 \pm 0.47$ & $12 \pm 0.47$ & $5 \pm 0.5$ & $8 \pm 0.81$ & $2 \pm 0.47$ & $8 \pm 0.47$ \\
\hline \multirow{7}{*}{ Trichoptera } & \multirow{5}{*}{ Hydropsychidae } & Homoplectra $s p$ & $1 \pm 0.47$ & $0 \pm 00$ & $0 \pm 00$ & $5 \pm 0.47$ & $0 \pm 00$ & $1 \pm 0.94$ \\
\hline & & Hydropsyche sp & $6 \pm 0.47$ & $15 \pm 0.94$ & $14 \pm 0.81$ & $18 \pm 0.47$ & $13 \pm 0.47$ & $12 \pm 0.94$ \\
\hline & & Potamiya $s p$ & $12 \pm 0.47$ & $8 \pm 0.47$ & $0 \pm 00$ & $7 \pm 0.47$ & $9 \pm 0.47$ & $1 \pm 0.47$ \\
\hline & & Macronema $s p$ & $6 \pm 0.47$ & $12 \pm 0.47$ & $0 \pm 00$ & $11 \pm 0.47$ & $0 \pm 00$ & $1 \pm 0.47$ \\
\hline & & Leptonema sp & $1 \pm 0.47$ & $0 \pm 00$ & $1 \pm 0.47$ & $0 \pm 00$ & $1 \pm 0.47$ & $1 \pm 0.94$ \\
\hline & Polycentropodidae & Polycentropus sp & $2 \pm 0.47$ & $3 \pm 0.47$ & $4 \pm 0.47$ & $3 \pm 0.47$ & $1 \pm 0.47$ & $1 \pm 0.47$ \\
\hline & Stenopsychidae & Stenopsyche sp & $8 \pm 0.47$ & $10 \pm 0.47$ & $2 \pm 0.5$ & $10 \pm 0.47$ & $5 \pm 0.47$ & $2 \pm 0.47$ \\
\hline
\end{tabular}

\begin{tabular}{|c|c|c|c|c|c|c|c|c|}
\hline Order & Family & Genera & Nov & Dec & Jun & Feb & Mar & April \\
\hline \multirow{7}{*}{ Ephemeroptera } & Beatidae & Beatis $s p$ & $15 \pm 0.81$ & $10 \pm 0.81$ & $11 \pm 0.81$ & $14 \pm 0.81$ & $15 \pm 0.81$ & $15 \pm 0.81$ \\
\hline & Leptophlebiidae & Choroterpes $s p$ & $4 \pm 0.47$ & $2 \pm 0.47$ & $1 \pm 0.47$ & $10 \pm 0.81$ & $7 \pm 0.81$ & $3 \pm 0.81$ \\
\hline & & Notophlebia $s p$ & $8 \pm 0.81$ & $4 \pm 0.81$ & $15 \pm 0.81$ & $3 \pm 0.47$ & $8 \pm 0.81$ & $10 \pm 0.81$ \\
\hline & Caenidae & Caenis $s p$ & $18 \pm 0.81$ & $10 \pm 0.47$ & $15 \pm 0.81$ & $18 \pm 0.47$ & $10 \pm 0.81$ & $5 \pm 0.81$ \\
\hline & Heptageniidae & Epeorus $s p$ & $2 \pm 0.47$ & $4 \pm 0.47$ & $5 \pm 0.47$ & $4 \pm 0.47$ & $18 \pm 0.81$ & $4 \pm 0.81$ \\
\hline & Tricorythidae & Tricorythodes $s p$ & $3 \pm 0.47$ & $1 \pm 0.47$ & $4 \pm 0.47$ & $2 \pm 0.47$ & $2 \pm 0.47$ & $3 \pm 0.47$ \\
\hline & Ephemeridae & Ephemera sp & $2 \pm 0.47$ & $1 \pm 0.47$ & $1 \pm 0.47$ & $4 \pm 0.47$ & $7 \pm 0.81$ & $2 \pm 0.81$ \\
\hline Plecoptera & Perlidae & Neoperla $s p$ & $10 \pm 0.81$ & $5 \pm 0.81$ & $3 \pm 0.81$ & $10 \pm 0.81$ & $25 \pm 0.81$ & $10 \pm 0.81$ \\
\hline \multirow{7}{*}{ Trichoptera } & \multirow{5}{*}{ Hydropsychidae } & Homoplectra $s p$ & $1 \pm 0.47$ & $0 \pm 0$ & $1 \pm 0.47$ & $1 \pm 0.47$ & $1 \pm 0.47$ & $0 \pm 0$ \\
\hline & & Hydropsyche sp & $10 \pm 0.81$ & $15 \pm 0.81$ & $10 \pm 0.81$ & $11 \pm 0.47$ & $18 \pm 0.81$ & $16 \pm 0.81$ \\
\hline & & Potamiya $s p$ & $1 \pm 0.47$ & $0 \pm 0$ & $1 \pm 0.47$ & $0 \pm 0$ & $1 \pm 0.47$ & $2 \pm 0.47$ \\
\hline & & Macronema sp & $0 \pm 0$ & $0 \pm 0$ & $0 \pm 0$ & $1 \pm 0.47$ & $1 \pm 0.47$ & $1 \pm 0.47$ \\
\hline & & Leptonema sp & $1 \pm 0.47$ & $0 \pm 0$ & $1 \pm 0.47$ & $0 \pm 0$ & $1 \pm 0.47$ & $1 \pm 0.47$ \\
\hline & Polycentropodidae & Polycentropus sp & $2 \pm 0.47$ & $1 \pm 0.47$ & $0 \pm 0$ & $1 \pm 0.47$ & $1 \pm 0.47$ & $1 \pm 0.47$ \\
\hline & Stenopsychidae & Stenopsyche $s p$ & $8 \pm 0.81$ & $4 \pm 0.81$ & $15 \pm 0.81$ & $3 \pm 0.47$ & $8 \pm 0.81$ & $10 \pm 0.81$ \\
\hline
\end{tabular}

